\title{
AMINO NITROGEN ANI) REDUCING SUGARS OF GREEN AND CHLOROPHYLL-DEFICIENT TYPES IN MAIZE ${ }^{1}$
}

\author{
Miriam Georgia Groner
}

IN THE experiments reported in this paper, corn seedlings were subjected to various conditions, both normal and abnormal, and the influence of these conditions upon the amino nitrogen and reducing sugar content of the seedlings was determined by analysis. The abnormal conditions used were carbohydrate starvation, artificial feeding of maltose or dextrose to seedlings kept under conditions in which they were unable to supply their own carbohydrates, and subjection to anaerobic conditions.

Plants of an albino type were particularly valuable in determining the effects of carbohydrate starvation and of feeding sugars artificially, because the carbohydrate supply of these plants could be cut off by merely removing the endosperm. When comparative experiments with green and albino seedlings were conducted, plants of the same parent stock and of exactly the same age were always selected. The same albino type, $w_{2} w_{2}$, was used in these experiments as was used in the respiration experiments which have been previously reported (Groner, 1936).

Preparation of Plant Material.-In each of these experiments from four to six plants were subjected to the desired conditions and extracted for analysis. The exact number of seedlings used depended upon the number of albinos appearing in the planting, and the number of parallel experiments to be conducted. As soon as the albino plants could be distinguished from the normal green seedlings, they were divided into groups and transplanted to pots. If parallel experiments were to be conducted with green seedlings, these were also transplanted to pots. All of these seedlings were grown in the greenhouse until the albino plants had reached a fairly large size. However, the plants were subjected to experimental conditions at least one week before untreated plants of the same age showed signs of having exhausted the food supply of the endosperm.

At the end of the experimental period the seedlings from each pot were cut off cleanly at the surface of the soil and placed in a previously weighed Erlenmeyer flask of $100-150 \mathrm{ml}$. capacity. All particles of soil were removed from the seedlings. The flasks were then placed in a drying oven for twenty-four hours at a temperature of $98^{\circ} \mathrm{C}$. The plants were always cut in the middle of the afternoon, because

1 Received for publication December 3, 1934.

Papers from the Department of Botany, University of Michigan, Number 496 .

During the time that these experiments were in progress, the author was holding an appointment to the F. C. and Susan Eastman Newcombe Fellowship in Plant Physiology, in the Department of Botany of the University of Michigan. This opportunity is taken to thank the Department for awarding the Fellowship, and for helpful suggestions and criticisms.
Schulze and Schütz (1909) have shown that total nitrogen varies regularly throughout the day, and it seemed reasonable to suppose that the various soluble fractions of nitrogenous material might show a similar variation.

On removal from the oven the flasks were placed in a desiccator to cool, and weighed just before their extraction for analysis. In dried condition the plants could be stored indefinitely without change, as the temperature of drying was high enough to destroy the natural enzymes of the plant, and in a desiccator, no decomposition could be brought about by the action of bacteria or fungi.

For analysis the dried plants were ground up as finely as possible with a stirring rod, without being removed from the flask. Then $25 \mathrm{ml}$. of distilled water were added to each flask, and the material was extracted for three hours on a boiling water bath. At the end of this time the extract was filtered and washed. If the total volume of the filtrate exceeded $50 \mathrm{ml}$., the extract was evaporated on a water bath to a volume of $25-30 \mathrm{ml}$. and made up to a volume of $50 \mathrm{ml}$. with distilled water, otherwise the volume was made up to $50 \mathrm{ml}$. directly. Ten milliliters of this extract were used for each amino nitrogen determination by the Van Slyke method (1912), and 0.5 $\mathrm{ml}$. for each determination of reducing sugar by the method of Hagedorn and Jensen (1923).

At the beginning of the experimental period, the endosperm was removed from those plants which were to be analyzed after a period of starvation, or after being artificially supplied with sugar. Dextrose and maltose were the only sugars used for feeding, because the results of respiration experiments (Groner, 1936) had shown that these sugars were most readily utilized by the plant when fed artificially. Five plants of uniform size were used in each of these experiments, and were supplied with $10 \mathrm{ml}$. of a 0.1 per cent solution of either dextrose or maltose every twenty-four hours. As the experiments were usually continued for about forty-eight hours, each pot of seedlings was supplied with $20 \mathrm{ml}$. of 0.1 per cent sugar solution, or, expressed in grams, with $0.02 \mathrm{~g}$. of sugar during the experimental period. When experiments of this type were conducted with green plants, they were placed in a dark-room as soon as the endosperm had been removed, and kept there until the end of the experiment. A pot of plants with endosperm was placed in the dark with the others to act as a control. Two pots of plants, one with and one without endosperm, were kept in the light to act as further controls. With albino seedlings, these experiments could be conducted in either light or darkness.

[The Journat for June (23: 381-452) was issued July 28, 1936.] American Journat of Botany, Vol. 23, No. 7, July, 1936 
TABLE 1. Comparison of the results obtained by extraction of plant material with and without precipitalion of proteins.

\begin{tabular}{cll}
$\begin{array}{c}\text { Type } \\
\text { of } \\
\text { plant }\end{array}$ & \multicolumn{2}{c}{$\begin{array}{c}\text { Water } \\
\text { extraction }\end{array}$} \\
Albino $\ldots \ldots \ldots$ & $.591 \%$ & R. Sug. \\
Green $\ldots \ldots \ldots \ldots$ & .1942 &
\end{tabular}

To subject the seedlings to anaerobic conditions in an atmosphere of nitrogen, a glass jar with a mouth large enough to admit a four and one-half inch pot was used. The pot of seedlings was placed within the jar, and the jar closed with a stopper and sealed with paraffin. This stopper was fitted with two pieces of glass tubing, one of which was attached to a series of chromous chloride bottles leading from a tank of nitrogen; and the other of which was connected with a safety bottle and an aspirator. A Y-tube was inserted in the system at the point where the gas entered the chamber. One arm of the $\mathrm{Y}$-tube was connected with the tube inserted in the stopper, and the other arm was connected with a mercury manometer. By just balancing the mercury columns in the manometer, the pressure within the chamber could be adjusted to that of the surrounding atmosphere. The length of time that the seedlings were in nitrogen was arbitrarily considered as beginning two hours after the plants were placed in the chamber, since two hours were assumed to be necessary for the complete replacement of the air within the chamber by nitrogen.

Preliminary experiments in extraction with 95 per cent alcohol and 10 per cent zinc sulphate solution in order to precipitate proteins gave results identical, within limits of experimental error, with those obtained from the analysis of water extracts. (See table 1.)

METHOD OF AMINO NITROGEN DETERMINATION.-In the amino nitrogen determinations a modification of the standard, large-sized Van Slyke apparatus was used. In place of the usual burette, graduated to 0.1 ml., one made specially according to the specifications of the author was substituted. The scale of this burette contained $12 \mathrm{ml}$ : and was graduated to 0.05 $\mathrm{ml}$. The bulb at the lower end of the scale, however, was of $250 \mathrm{ml}$. capacity, so that the volume of mixed gases obtained from the reagents used could be easily accommodated.

A burette of this type was very satisfactory because a relatively large amount of the plant extract yielded but little nitrogen, $10 \mathrm{ml}$. of the extract giving only 0.6 to $3.5 \mathrm{ml}$. of nitrogen after the oxides of nitrogen had been absorbed by the alkaline permanganate. With a more concentrated plant extract, either of the standard types of Van Slyke apparatus could have been used, but as the amount of available plant material was rather limited, a dilute extract analyzed in the modified apparatus, permitted the available material to be used over a much wider series of ex-
$10 \%$ zinc sulphate extraction

$\begin{array}{ll}\text { Am. N. } & \text { R. Sug. } \\ .605 \% & 5.09 \%\end{array}$
$5.09 \%$

periments than would otherwise have been possible. A second advantage was that these dilute extracts caused but little foaming when shaken with the nitrous acid, whereas more concentrated extracts, particularly from the green plants, gave considerable trouble on this score. With the more finely graduated scale the amount of gas obtained could be estimated very accurately.

As the occurrence of urea in certain plants has been reported by Fosse $(1913,1914)$, and Chibnall (1922) has reported the presence of urea derivatives in leaves of the runner bean, the possibility that nitrogen from such sources might influence the results was considered. Green and albino plants were analyzed $^{2}$ for total urea and ammonia nitrogen under normal conditions, and were found to contain about 0.004 per cent of fresh weight, or 0.04 per cent dry weight of plant material, of these substances in both types of seedlings. Another investigator (Wood 1933) has shown that under the usual experimental conditions, amide nitrogen does not influence the results of amino nitrogen determinations by the Van Slyke method.

Method of Reducing-sugar determination.-For the determination of the quantity of reducing sugar present in the plant, the micro method of Hagedorn and Jensen (1923) was used. By experiment, $0.5 \mathrm{ml}$. of the plant extract was found to contain reducing sugar in amounts equivalent to those present in 0.1 ml. of blood.

The method depends upon the reduction of a standard solution of potassium ferricyanide by the sugars in the unknown, and the subsequent iodometric titration of the residual ferricyanide against a standardized $0.0025-0.005 \mathrm{~N}$. sodium thiosulphate solution. As the method has only been standardized for glucose, the results were all calculated as glucose.

Precipitation of the proteins before determining sugars was found to be unnecessary with the extracts used. As stated in the original paper of Hagedorn and Jensen (1923), the purpose of this precipitation was to eliminate the small amount of iron which is present in the proteins of the blood. The extract used was tested for iron ${ }^{3}$ and found to give no re-

2 These determinations were made by Mr. Sam Granick, Newcombe Frllow in the Department of Botany, University of Michigan.

3 The test for iron was the following: $5 \mathrm{ml}$. of $1 \mathrm{per}$ cent potassium ferricyanide with $1 \mathrm{ml}$. of the extract, 1 drop of 10 per cent sulphuric acid, and 1 drop of potassium ferrocyanide solution should show no trace of Prussian bluc. (Lower limits, $0.01 \mathrm{mg}$. of iron.) 
TABLE 2. Results from the analysis of green and albino seedlings for amino nitrogen (Van Slyke method), and reducing sugars (Hagedorn-Jensen method), expressed in percent dry weight of leaf material. Experiments of the same number were conducted with seedlings of the same age and parent stock. A.N.-Amino nitrogen. R.S.-Reducing sugar.

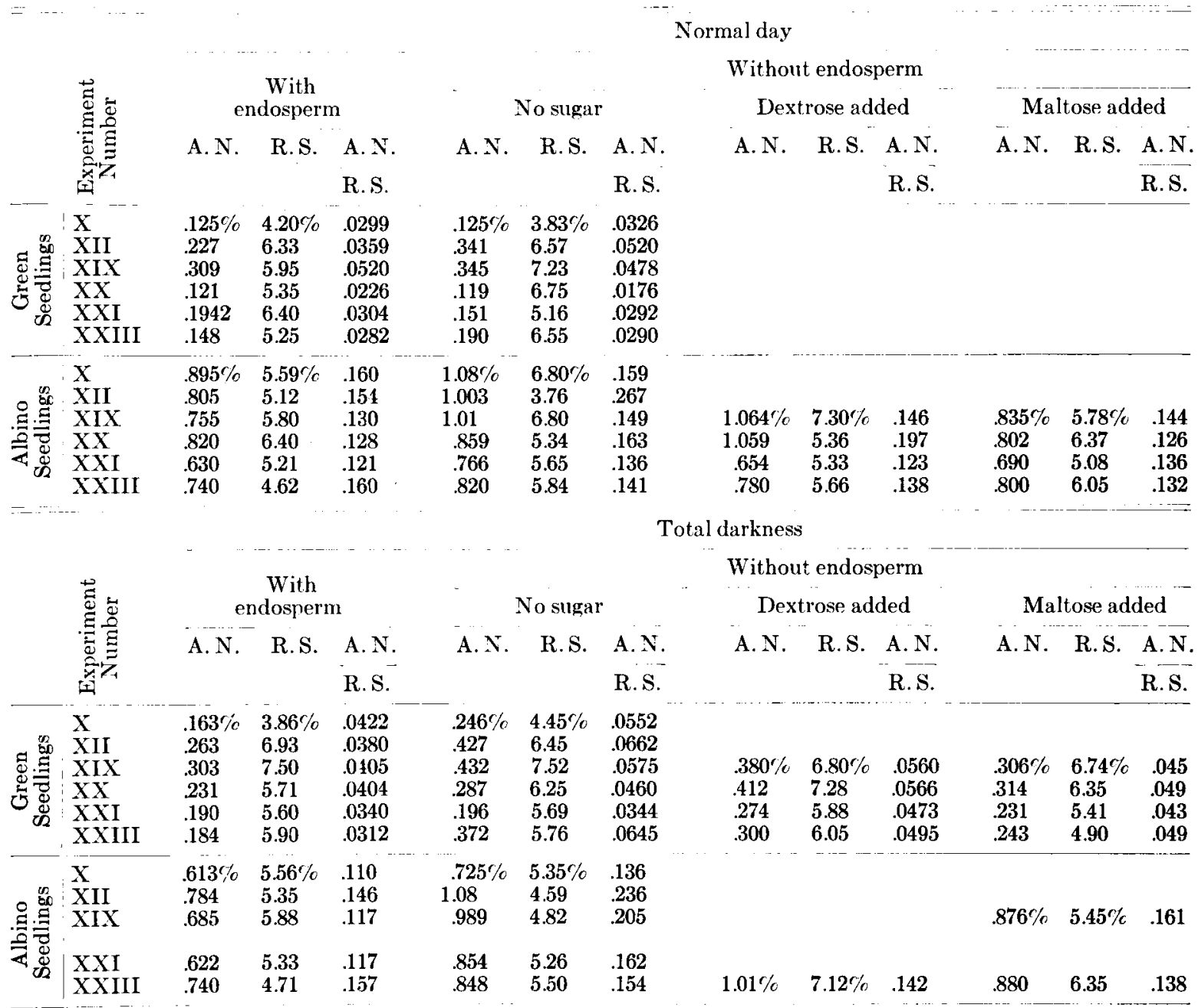

action. In addition to this, samples were analyzed, with and without zinc hydroxide precipitation, and were found to give results which were practically identical, within limits of experimental error.

To $0.5 \mathrm{ml}$. of the plant extract, water to a total volume of $14 \mathrm{ml}$. and exactly $0.5 \mathrm{ml}$. of a $0.005 \mathrm{~N}$. alkaline potassium ferricyanide solution were added. The mixture was heated on a boiling water bath for 15 minutes: At the end of that time the tubes were removed from the water bath and cooled rapidly in cold, running water.

Then $1 \mathrm{ml}$. of a solution containing $5 \mathrm{~g}$. of potassium iodide in $66.6 \mathrm{ml}$. of water; $2 \mathrm{ml}$. of a solution containing $10 \mathrm{~g}$. of zinc sulphate and $50 \mathrm{~g}$. of sodium chloride in $133.3 \mathrm{ml}$. of water; and $2 \mathrm{ml}$. of 3 per cent acetic acid were added. After shaking well, two drops of standard starch indicator were added, and the free iodine in the mixture was titrated against a standard solution of approximately $0.005 \mathrm{~N}$. sodium thiosulphate.
For the titrations a five milliliter burette, graduated to $0.05 \mathrm{ml}$., was used.

The number of milligrams of glucose equivalent to the amount of thiosulphate required for the titration was obtained from a table, found either in the "Handbook of Chemistry and Physics" (Hodgeman and Lange, 1928), Hawke and Bergheim's "Physiological Chemistry" (1926), or in the original paper of Hagedorn and Jensen (1923). From this value the amount of glucose equivalent to the reduction shown by a $15 \mathrm{ml}$. water blank was subtracted, and the amount present in the entire $50 \mathrm{ml}$. sample, and in the original dry weight of plant material calculated.

Results AND DIscussron.-Table 2 is a compilation of all of the results obtained from the analysis of green and albino seedlings for amino nitrogen and rerlucing sugars, under normal conditions, after being kept under conditions of carbohydrate starvation, and after being artificially supplied with dextrose and maltose. These results are expressed in percentage 
dry weight of plant material, and are combined in a single table in order to facilitate comparison. Under each series of experimental conditions-for example, normal day, without endosperm, and no sugar addedthree figures are given. These figures are amino nitrogen content (Van Slyke), reducing sugar content (Hagedorn and Jensen), and the ratio of amino nitrogen to reducing sugar. All experiments bearing the same number were conducted with seedlings of the same age and parent stock. The seedlings used in different experiments varied in age from ten days to two weeks, depending upon their size. The results reported are averages of closely checking duplicate or triplicate analyses. The figures in each column, for seedlings of a single type, are comparable in the conditions which were purposely varied, but cannot be averaged because of uncontrollable differences in light intensity brought about by varying weather conditions during the time the seedlings were kept in the greenhouse.

Table 2 is divided into four main sections: one for results of experiments with green seedlings kept in the greenhouse, where they were subject to a normal day of approximately twelve hours light and twelve hours darkness; one for green seedlings kept in a darkroom throughout the experimental period; one for albino seedlings kept in the greenhouse; and one for albino seedlings kept in total darkness during the experimental period. The series of experiments with seedlings exposed to a normal day, and to total darkness, are further divided into experiments with seedlings with the endosperm present, and consequently under normal nutritional conditions; and experiments with seedlings from which the endosperm had been removed. The experiments with seedlings without endosperm are further subdivided into those with no sugar added, and those in which either dextrose or maltose was supplied.

The following points are apparent from a study of this table. (a) The albino seedlings contained a much larger percentage of amino nitrogen than normal green seedlings of the same age and parent stock. (b) The removal of endosperm from the green seedlings did not bring about an increase in amino nitrogen content as long as they were kept in the greenhouse where there was adequate light for photosynthesis. (c) Neither green nor ablino seedlings, with endosperm present, showed a marked accumulation of amino nitrogen when kept in the dark. A slight increase may be explained on the basis of the normal movement of amino acids in the dark which has been demonstrated by Suzuki (1896). (d) Either green or albino seedlings, without endosperm, showed a definite accumulation of amino nitrogen when kept in the dark without being artificially supplied with sugar. (e) Albino seedlings, without endosperm, showed a similar amino nitrogen accumulation in the light. (f) The feeding of either dextrose or maltose tends to inhibit the accumulation of amino nitrogen noted under conditions of carbohydrate starvation. (g) Reducing sugar content tends to remain fairly constant throughout the series of experiments.
Maltose and dextrose were selected for use in artificial feeding, because they are the sugars most likely to be present normally in the young seedling, particularly in the albino, which is entirely dependent on the hydrolysis products of the starch in the endosperm for its supply of carbohydrates. In these experiments, maltose seems to be slightly more effective than dextrose in inhibiting amino nitrogen accumulation. The author recognizes the fact that these results are not in accordance with all of the findings of other investigators concerning the availability of different sugars, but they seem very reasonable in view of the fact that young seedlings, entirely dependent on the hydrolysis products of starch, are in all probability well adapted to the utilization of maltose. The plants that were supplied with maltose showed practically normal growth during the period following the removal of the endosperm, whereas those which were not supplied with sugar failed to increase in size. The seedlings which were supplied with dextrose showed some growth, but not as much as those which were supplied with maltose.

These results indicate that in the absence of an adequate supply of carbohydrates, the proteins of the plant are broken down and oxidized to supply energy for the plant. Mothes (1925) has obtained very similar results with young leaves of Phaseolus and Lupinus.

The figures for reducing sugar content show that conditions of carbohydrate starvation failed to bring about any marked decrease in the reducing sugar content of the leaf, which suggests that at least part of the amino acids resulting from the hydrolysis of proteins may have been deaminized and synthesized into glucose, or some compound similar to glucose which reduces ferricyanide, before being broken down to carbon dioxide and water. Dakin (1913, 1919), Dakin and Dudley (1914), Janney (1915), Lusk (1908, 1928), Ringer (1913, 1914), Ringer and Lusk (1910), have found that a large number of amino acids give rise to glucose in the diabetic animal. By feeding different amino acids to phlorhizinized dogs, all straight chain amino acids up to six carbons in length, dicarboxylic amino acids, proline, oxyproline, and arginine were found to be at least partially convertible to glucose. Lysine, leucine, isoleucine, valine, phenylalanine, tyrosine, tryptophane, and histidine did not give rise to glucose. If such a situation as this occurs in the animal, it seems reasonable to believe that the plant might also convert amino acids to glucose under certain conditions. The possibility of converting or not converting these amino acids to glucose depends upon their chemical structure. The amino acids must be so constituted as to give rise to at least one three-carbon chain in order to be partially or wholly convertible to glucose. The only exception is lysine, which theoretically should give rise to glucose, but fails to do so.

The accumulation of amino nitrogen can be explained as the accumulation of those amino acids set free by the hydrolysis of protein, which are not convertible to glucose. The ammonia set free by the 
TABLE 3. Results from the analysis of virescent seedlings in progressive stages of chlorophyll development for amino nitrogen and reducing sugars. A.N.-Amino nitrogen. R.S.-Reducing sugar.

White $\quad 1 / 2$ Green $\quad 3 / 4$ Green

A. N. R.S. A.N.

A. N. R.S. A. N.

A. N. R.S. A.N.

R.S.

R.S.

Entirely green

Older green

Number

R.S.

XVII

$.905 \% \quad 9.63 \% \quad .094$

$\begin{array}{llll}\mathrm{XVIII} & .917 & 8.50 & .108\end{array}$

$\begin{array}{llll}\mathrm{XXII} & .633 & 7.56 & .0837\end{array}$

$.624 \% \quad 5.78 \% \quad .108$

$\begin{array}{lll}.553 & 6.06 & .0913\end{array}$

$.535 \% \quad 5.94 \% \quad .0902$

$\begin{array}{lll}.428 & 6.45 \quad .0664\end{array}$
A. N. R.S. A.N.

R.S.

R.S.
$.375 \% \quad 5.30 \% \quad .0708$

$\begin{array}{lll}.354 & 5.57 & .0635\end{array}$ deaminization of amino acids was probably bound as asparagine or glutamine.

It is interesting to note that the amino acids, alanine and glycine, which Spoehr and McGee (1923) found to stimulate respiration, were sugar formers in the phlorhizinized animal, and that no acceleration of respiratory rate was brought about by the amino acids which accumulate in the albino (Groner, 1936).

Of course it is possible that some of the threecarbon intermediates, between amino acids and glucose, such as pyruvic acid, might reduce ferricyanide. Neubauer and Fromherz (1910) have suggested that pyruvic acid may arise from amino acids such as alanine, and Mayer (1914) believes that pyruvic acid may be an important intermediate between aspartic acid and glucose in the diabetic animal. That pyruvic acid is convertible to glucose in phlorhizinized dogs has been shown definitely by Dakin and Janney (1913), and Ringer (1914). Spoehr and Strain (1930) have shown that methyl-glyoxal is easily converted to lactic acid by heating in aqueous solution, and it is doubtful if lactic acid would reduce the ferricyanide. Acetaldehyde, if present, would have volatilized during the three-hour hot extraction. It does not seem reasonable to suppose that either pyruvic or lactic acid would be present in sufficient quantities to produce an appreciable error in the results.

A comparison of respective amino nitrogen content shows that the albino seedlings contained a much larger percentage than normal green seedlings of the same age and parent stock, even when provided with an adequate supply of carbohydrates. In an attempt to explain this phenomenon, virescent seedlings in progressive stages of chlorophyll development were analyzed. The results are summarized in table 3 .

Virescent is a genetic type found in corn, in which the seedling comes up white, but under favorable conditions of light and temperature, gradually develops chlorophyll, and in the course of two or three weeks acquires the appearance of a normal green seedling. Demerec (1924) has studied the genetics of the virescent type, and has found five pairs of factors, $v_{1}-v_{5}$, which may be responsible for its occurrence. The plants used by the author were of the constitution $v_{1}-v_{1}$. Miles (1914-1915) has studied the histology of plastid development in virescent seedlings, and has found that the young plants contain small, plastid-like bodies which enlarge as the plant develops and turn green like those of normal plants.

The figures shown in column 1 were obtained from the analysis of plants four to five days old, which were white, with the exception of a small green area at the tip of the older leaf. Younger plants were not analyzed because the amount of available seed producing this type was rather limited, and with such small plants, too large a number of them would be required for an analysis. The figures in column 2 were obtained from plants which were about one-half green; column 3, from plants three-quarters green; column 4, from plants which had just attained the appearance of normal green plants; and column 5, from plants which had been normal green in appearance for about ten days.

These results indicate clearly that the high amino nitrogen content is correlated with the absence of chlorophyll, rather than with lack of plastids. As it is known that the chlorophyll molecule contains nitrogen, it is reasonable to suppose that under normal conditions the original nitrogen supply for use in chlorophyll synthesis comes from the endosperm. Pettibone and Kennedy (1916) have analyzed the sap obtained from the bleeding of decapitated corn coleoptiles, and have found that amino acids for use in anabolic processes were present. In plants of an albino type, which, for some as yet unknown reason are unable to synthesize chlorophyll, it is possible that this excess supply of amino acids is not used up, but tends to accumulate in the seedling. Possibly the amino acids which furnish the nitrogen for chlorophyll synthesis are some of those which are not readily deaminized and oxidized to provide energy for the life processes of the plant.

In green seedlings which were grown entirely in the dark there was a decided increase in both amino nitrogen and reducing sugar content, whereas the amino nitrogen content of the albinos which were grown in the dark showed a decrease as compared with plants of the same age which were grown under normal conditions. However, the reducing sugar content of the albinos, grown in the dark, showed a decided increase. Figures for this are given in table 4 .

Schulze and Castoro (1903) have reported an increase in amino nitrogen in etiolated seedlings, and believed that it was caused by the breaking down of proteins. However, the fact that such an increase does not occur in the albino indicates that some other factor must be involved. The seedings which were analyzed to obtain the data presented in table 4 had not exhausted the carbohydrate supply of the endosperm when they were gathered.

Eyster (1933) has shown that the amount of total chlorophyll in green seedlings varies from $3.7 \mathrm{mg}$. to 
TABLE 4. Comparison of normal and etiolated seedlings of the green and albino types.

Amino nitrogen

\begin{tabular}{|c|c|c|c|}
\hline Type of plant & Amino nitrogen & Reducing sugar & Reducing sugar \\
\hline Green-normal & $0.302 \%$ & $5.43 \%$ & .056 \\
\hline Green-etiolated & $0.765 \%$ & $8.34 \%$ & .092 \\
\hline Albino-normal & $0.890 \%$ & $5.27 \%$ & 169 \\
\hline Albino-etiolated & $0.650 \%$ & $9.45 \%$ & .069 \\
\hline
\end{tabular}

$7.04 \mathrm{mg}$. per gram of dry leaf powder. The amount of nitrogen necessary for the synthesis of these amounts of chlorophyll is calculated as varying from $0.2262 \mathrm{mg}$. to $0.43 \mathrm{mg}$. per gram dry weight. In the virescent seedlings the drop in amino nitrogen during the time that chlorophyll was developing amounted to $5.42 \mathrm{mg}$. per gram dry weight in experiment XVIII, and to $3.755 \mathrm{mg}$. in experiment XXII. These figures indicate that some other factor than chlorophyll synthesis must be involved in bringing about this drop in amino nitrogen content.

Knudson and Lindstrom (1919) have stated that diffusion of sugars from the roots to the leaves in albino plants is slow. It is possible that the diffusion of sugars from the endosperm in virescent and albino seedlings is too slow to furnish the plant with a completely adequate supply of carbohydrates, and that proteins are being broken down and oxidized, accounting for the extra amino nitrogen which is not used in chlorophyll synthesis. As the leaves of the virescent plants develop chlorophyll, the carbohydrates which are manufactured in the leaves exert a protein sparing action, and depress the amount of free amino nitrogen in the leaves to a normal level.

Total nitrogen was not determined quantitatively, but in view of the findings of Lakon (1917) with variegated leaves of Acer Negundo, Acer pseudoplatanus, Sambucus nigra, Vinca major, Tradescantia zebrina, Abutilon vexillarium, and Aegopodium Podagraria, the leaves of the green and albino plants were tested qualitatively for proteins by his methods. The leaves were first placed in scalding water and then transferred to warm alcohol until the green leaves became colorless, after which they were tested for protein by the xanthoproteic, biuret, and Millon reactions. In Acer pseudoplatanus, for example, which has intense green, bright green, and pure white stripes, Lakon found that the white stripes showed only a trace of coloration, and the dark green portion showed a very intense reaction with both the biuret and Millon reagents. It is assumed that the intensity of the protein reaction depends upon the number of chloroplasts present, and that the faint protein test in colorless regions came from cytoplasm. Ullrich (1924) has also suggested that plastids are necessary for protein synthesis. Both types of corn seedlings gave very distinct reactions with these protein tests, particularly with the biuret, although the reaction was slightly stronger in the green plants. Although these tests for the presence of proteins are not particularly satisfactory, the results seem to indicate that protein synthesis may take place rather extensively in the absence of plastids.
As was previously mentioned, green and albino seedlings were found by analysis to contain approximately equal amounts of ammonia nitrogen; consequently, the large differences in amino nitrogen content were not caused by an accumulation of substances of this type, which would probably react with nitrous acid. After this investigation had been completed, the work of Stuart (1935) came to the author's attention. This worker found that ammonia in certain plants, such as Begonia, introduces a serious error in the quantitative determination of amino nitrogen by the Van Slyke method. In other plants, such as the soy bean, the error was not large.

Another investigator (Wood, 1933) has shown that under the usual experimental conditions, amide nitrogen does not influence the results of amino nitrogen determination by the Van Slyke method. However, Chibnall and Westall (1932) have shown that under certain conditions of hydrogen-ion concentration the amide nitrogen of glutamine may react with nitrous acid and introduce a serious error. With the $\mathrm{pH}$ range of the writer's experiments, however, it is doubtful if this source of error was present.

Table 5 is compiled from the results of analyses of seedlings which had been subjected to anaerobic conditions. The results for the green seedlings show a slight increase in amino nitrogen under anaerobic conditions, which is in accordance with the findings of Mothes (1925) for Lupinus and Phaseolus. However, the albino usually shows a decided decrease, which is difficult to explain. The reducing sugar content remains about the same throughout the series of experiments, except for an increase in the green seedlings at 48 hours.

General. Discussion. - The results obtained from the analysis of young corn seedlings are very different from those obtained by Spoehr and McGee (1923) from the analysis of mature, excised leaves of Helianthus, and the "Canada Wonder Bean." However, the results with corn are in agreement with those of Mothes (1925), who analyzed fairly young, attached leaves of Vicia faba, Lupinus luteus, and Phaseolus multiflorus. These plants belong, as does corn, to the group of "amide" plants of Ruhland and Wetzel (1926, 1929), and results relating to their nitrogen metabolism should be generally comparable. In these " amide" plants the proteins give rise by hydrolysis to amino acids, which undergo oxidative deaminization and produce asparagine or glutamine, either from the aminization of succinic or malic acid (produced in respiration) by ammonia, or the whole molecule of asparagine might arise from such amino acids as glutaminic acid or leucine by oxidation. 
TABLE 5. Results obtained from the analysis of green and albino seedlings for amino nitrogen and reducing sugars after being subjected to anaerobic conditions. As a control, seedlings of the same age and parent stock as the experimental plants were kept under normal conditions. A.N.-Amino nitrogen. R.S.-Reducing sugar."

24 hours in nitrogen

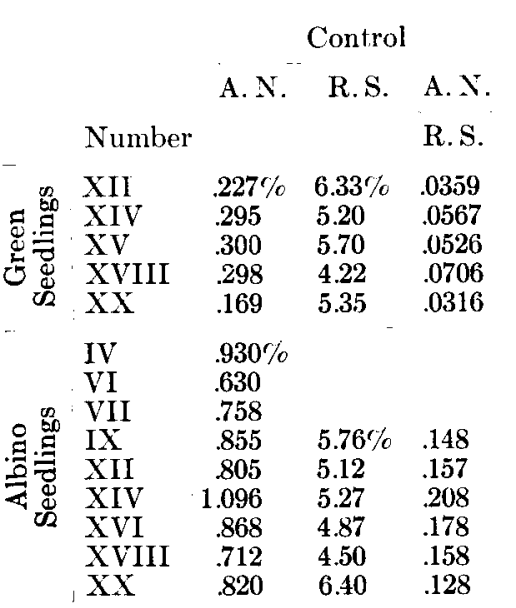

Mothes (1925) did not determine amino nitrogen by the Van Slyke method, but instead determined ammonia, two-amide, soluble, and protein nitrogen, and calculated amino nitrogen by difference. Although his results are expressed in percentage of total nitrogen rather than in percentage of dry weight, the directions of fluctuation under similar conditions are of course comparable. His results from experiments on the feeding of sugars agree particularly well with the findings of the author.

These results with sugar feeding seem very reasonable in accordance with the idea that carbohydrates act as protein sparers, as suggested by Deleano (1912) from the results of his experiments with Vitis vinifera. When leaves of this plant were kept in the dark, only carbohydrates were utilized during the first hundred hours; thereafter drastic disturbances in the proteinaceous components of the leaf occurred. Leaves of Vitis are known to store large quantities of carbohydrates. Chibnall (1924) has reported an accumulation of amino nitrogen under conditions of starvation, and the relatively high production of carbon dioxide (Groner, 1936) during periods of carbohydrate starvation indicates that the proteins of the plant must have been utilized. In the animal, this protein sparing action of carbohydrates has long been recognized.

Schulze (1900) and Prianischnikow (1899, 1922) seem to agree that plant proteins are primarily decomposed into their component amino acids, although they differ upon the subject of the function of asparagine. Part of the amino nitrogen obtained in the Van Slyke determinations probably came from asparagine, but, since asparagine and amino nitrogen are labile forms, and since their fluctuations in abundance, according to Mothes (1925), tend to follow similar curves under conditions of starvation, asparagine was not determined separately, as the amount of material was insufficient.
48 hours in nitrogen Normal day

A. N. R.S. A. N. A. N R.S. A. N. R.S.

R.S.

$.635 \% \quad 7.30 \% \quad .0870$

$.235 \quad 7.04 \quad .0334$ $.404 \% \quad 6.90 \% \quad .0585$ $\begin{array}{lll}.400 & 5.25 & .0761\end{array}$

.0625

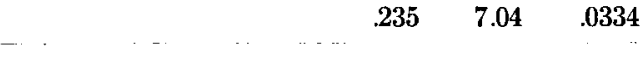

122

$.975 \% \quad 5.24 \% \quad .186$

$\begin{array}{lll}.900 & 4.17 & .216\end{array}$

$\begin{array}{lll}.894 & 5.25 \quad .170\end{array}$

$\begin{array}{lll}515 & 11.17 \quad .460\end{array}$

That maltose is the sugar most easily utilized by the young corn seedling seems to be quite clearly indicated, both by the respiration data (Groner, 1936) and by the corroborative evidence of its prevention of protein decomposition and subsequent accumulation of amino nitrogen. Experiments with green seedlings prove that this ready use of maltose is not merely a peculiarity of the albino type, but also occurs in normal seedlings. Dextrose is apparently more readily available to the normal green seedling than to the albino.

Brown and Morris (1893) report that they have isolated maltose in considerable quantities from the leaves of Tropaeolum, but Davis, Daish, and Sawyer (1916) and Davis and Sawyer (1916) failed to find maltose in this plant, as well as in several others which they tested.

It is possible that maltose, in the leaves of higher plants, occurs only as an intermediate in the hydrolysis of starch, and is so rapidly converted into simpler substances that it is difficult to detect without the use of agents to bind it in an inactive form, analogous to those methods used by Neuberg and Gottschalk (1925), Neuberg and Kobel (1930), Klein and Pirschle (1926), and Wetham (1927) in isolating the two and three carbon intermediates of anaerobic respiration.

\section{SUMMARY}

Corn seerllings of normal green and albino types were analyzed for amino nitrogen and reducing sugars after having been subjected to normal and starving conditions, artificially supplied with maltose and dextrose, and kept under anaerobic conditions. A water extract of the dried leaves was analyzed for amino nitrogen by the Van Slyke method, and for reducing sugars by the method of Hagedorn and Jensen.

Albino seedlings were found to contain from three to five times as much soluble amino nitrogen as green 
seedlings of the same age and parent stock. Under conditions of carbohydrate starvation, amino nitrogen showed a definite accumulation in either light or darkness. As amino nitrogen did not show an increase when the seedlings were supplied adequately with carbohydrates, irrespective of light or darkness, it is concluded that carbohydrates exert a protein sparing influence in plants, similar to that found in animals. Accumulation of amino nitrogen in leaves, which was observed under conditions of carbohydrate starvation, is believed to be the result of the decomposition of proteins for use in respiration. Etiolated seedlings of either type showed an increase in reducing sugar content, but only the green seedlings showed an increase in amino nitrogen.

The feeding of either maltose or dextrose to seedlings deprived of their normal supply of carbohydrates by the removal of endosperm tended to inhibit the accumulation of amino nitrogen. Maltose, however, was the more effective of the two, possibly because it is more readily converted to a labile, easily oxidized form of hexose.
Throughout most of the experiments the reducing sugar content of the seedlings remained fairly constant, indicating that certain amino acids probably give rise to reducing sugars in the plant, tending to keep the percentage constant.

The results of analyses of virescent seedlings in progressive stages of chlorophyll development. indicate that an abnormally high amino nitrogen content, such as that found in the albino, is correlated with chlorophyll deficiency. As chlorophyll develops, the amino nitrogen content gradually decreases until it reaches the level of that of normal green seedlings. This decrease is probably best explained on the basis of the protein sparing action of the carbohydrates which are formed in the leaf as soon as an adequate supply of chlorophyll has been developed, although some of the excess amino nitrogen is probably used in chlorophyll synthesis.

\section{DEPaRTMENT OF BotaNy, UNiversity of Michigan}

\section{LITERATURE CITED}

Brown, H. T., AND G. H. MorRus. 1893. A contribution to the chemistry and physiology of foliage leaves. Jour. Chem. Soc. 63: 604-683.

Chibnal., A. C. 1922. Distribution of nitrogen in the dead leaves of the runner bean. Biochem. Jour. 16: $344-362 ; 608-610$.

1924. Investigation of the nitrogenous metabolism of the higher plants. IV. The role of asparagine in the metabolism of the mature plants. Biochem. Jour. 18: 395-404.

—, AND R. G. Westall. 1932. Estimation of glutamine. Biochem. Jour. 26: 122.

Dakin, H. D. 1913 . Studies on the intermediary metabolism of amino-acids. Jour. Biol. Chem. 14: 321333.

333. 1919. On amino-acids. II. Hydroxyglutamic acid. Biochem. Jour. 13: 398-429.

$\longrightarrow$, AND H. W. Dudrey. 1914. The fate of $l$-alanine in the glycosuric organism. Jour. Biol. Chem. 17: 451-454.

— AND N. W. JANNEY. 1913. The biochemical relation between pyruvic acid and glucose. Jour. Biol. Chem. 15: 177-180.

Davis, W. A., A. J. Daish, and G. C. Sawyer. 1916. Studies of the formation and translocation of carbohydrates in plants. I. The carbohydrates of the mangold leaf. Jour. Agr. Sci. 7: 255-326.

- AND G. C. SAW Yer. 1916. Studies of the formation and translocation of carbohydrates in plants. III. The carbohydrates of the leaf and leaf stalks of the potato. The mechanism of the degradation of starch in the leaf. Jour. Agr. Sci. 7: 352-384.

Deleano, N. 'T. 1912. Studien über den Atmungsstoffwechsel abgeschnittener Laubblätter. Jahrb. Wiss. Bot. 51: 541-592.

Demerec, M. 1924. Genetic relations of five factor pairs for virescent seedlings in maize. Cornell Univ. Agr. Exp. Sta. Mem. 84: 1-38.

Exster, W. H. 1933. Plastid studies in genetic types of maize: argentia chlorophyll. Plant Physiol. 8: 105121.
Fosse, M. R. 1913. Formation de l'urée par les végétaux supérieurs. Compt. Rend. Acad. Sci. Paris 156: $567-568$.

- 1914. Présence simultanée de l'urée et de l'uréase dans le même végétal. Compt. Rend. Acad. Sci. Paris 158: 1374-1376.

Groner, M. G. 1936. Respiration of green and chlorophyll-deficient types in maize. Amer. Jour. Bot. 23: 381-385.

Hagedorn, H. C., ANd B. N. Jensen. 1923. Mikrobestimmung des Blutzuckers mittels Ferricyanide. Biochem. Zeitschr. 135: 46-58.

Hawke, P. B., ANd O. Bergheim. 1926. Practical physiological chemistry. Philadelphia.

Hodgeman, C. D., ANd N. A. Lange. 1928. Handbook of chemistry and physics. Cleveland.

JANNEY, N. W. 1915. The metabolic relationship of proteins to glucose. Jour. Biol. Chem. 20: 321-350.

Klein, G., ANd K. Pirschle. 1926. Acetaldehyde als Zwischenprodukt der Pflanzenatmung. Biochem. Zeitschr. 168: 340-360.

Knudson, L., ANd E. W. Lindstrom. 1919. Influence of sugars on the growth of albino plants. Amer. Jour. Bot. 6 : 401-406.

LaKon, G. 1917. Der Eiweissgehalt panachierter Blätter geprüft mittels des makrospokischen Verfahrens von Molisch. Biochem. Zeitschr. 78: 145-154.

Lusk, G. 1908. The production of sugar from glutamic acid ingested in phlorhizin glycosuria. Amer. Jour. Physiol. 22: 174-178.

1928. The elements of the science of nutrition. Philadelphia.

Mayer, P. 1914. Beitrag zur Frage der Kohlensüurebildung durch Organe. Biochem. Zeitschr. 62: 462469.

Mrles, F. C. 1914-1915. Albinism in maize. Jour. Genetics 4: 193-214.

Mothes, K. 1925. Fin Beitrag zur Kenntnis des N-Stoffwechsels höherer Pflanzen (Unter Ausschluss des Keimlingsstadiums und unter besonderer Berucksichtigung der Säureamide). Planta 1: 472-552. 
Neubauer, O., añd K. Fromherz. 1910-1911. Uber den Abbau der Aminosäuren bei der Hefegärung. Zeitschr. Physiol. Chemie 70: 326-350.

Neuberg, C., axd A. Gottschalk. 1925. Utber den Nachweis von Acetaldehyde als Zwischenstufe bei der anaeroben Atmung höherer Pflanzen. Biochem. Zeitschr. 160: 256-260.

— ANd M. Kobes. 1930. Über den Verlauf der Brenztraubensäurebildung bei der Hefen-gärung. Biochem. Zeitschr. 219: 490-494.

Pettibone, C. J. V., and C. Kennedy. 1916. Translocation of seed protein reserves in the growing corn seedling. Jour. Biol. Chem. 26: 519-525.

Prianischnikow, D. 1899. Eiweisszerfall und Fiweissrückbildung in den Pflanzen. Ber. Deutsch. Bot. Ges. 17 : 151-155.

_- 1922. Ueber den Aufbau und Abbau des Asparagins in den Pflanzen. Ber. Deutsch. Bot. Ges. 40: $242-248$.

Ringer, A. I. 1913. The chemistry of gluconeogenesis. $V$. The role of pyruvic acid in the intermediary metabolism of alanine. Jour. Biol. Chem. 15: 145152.

- 1914. The chemistry of gluconeogenesis. VII Concerning the fate of pyruvic acid in metabolism. Jour. Biol. Chem. 17: 281-285.

—, AND G. Lusk. 1910. Uber die Entstehung von Dextrose aus Aminosäturen bei Phlorhizinglykosuric Zeitschr. Physiol. Chemie 66: 106-119.

Ruhland, W., and K. Wetzel. 1926. Zur Physiologie der organischen Säuren in grünen Pflanzen. I. Wechselbeziehungen im Stickstoff und Säurestoffwechsel von Begonia semperflorens. Planta 1: 558564.

, and K. Wetzel. 1929. Zur Physiologie de organischen Säuren in grünen Pflanzen. V. Weitere
Untersuchungen an Rheum hybridum Hort. Planta 7: 503-507.

Schulze, B., and J. Schütz. 1909. Die Stoffwandlungen in den Laubblättern des Baumes, inbesondere in ihren Bezichungen zum herbstlichen Blattfall. Landw. Versuchs.-Stat. 71: 299-352.

Schulze, F. 1900. Uber den Umsatz der Eiweissstoffe in der lebenden Pflanze. Zeitschr. Physiol. Chemie 30: 241-312.

— ANd N. Castoro. 1903. Beiträge zur Kenntnis der Zusammensetzung und des Stoffwechsels der Keimpflanzen. Zeitschr. Physiol. Chemie 38: 199 256.

Spoenr, H. A., ANd J. M. McGeE. 1923. Studies in plant respiration and photosynthesis. Carnegie Inst. Washington Publ. 325: 1-75.

_ AND H. H. Strain. 1930. The effect of weak alkalies on the trioses and on methylglyoxal. Jour. Biol. Chem. 89: 503-525.

Stuart, NeIL W. 1935. Determination of amino nitrogen in plant extracts. Plant Physiol. 10: 135-148.

Suzu KI, W. 1896. Bull. Coll. Agr. Tokyo 2: 458.

Ulirich, H. 1924. Die Rolle der Chloroplasten bei der Eiweissbildung in den grünen Pflanzen. Zeitschr. Bot. 16: 513-562.

VAN StyKe, D. D. 1912. The quantitative determination of aliphatic amino groups. II. Jour. Biol. Chem. 12: 275-284.

Wheтнам, M. D. 1927. The origin of acetaldehyde in bacterial and animal metabolism. Australian Jour. Exp. Biol. and Med. Sci. 4: 35-56.

Williams, R. J. 1931. An introduction to biochemistry. New York.

Woon, J. G. 1933. The nitrogen metabolism of the leaves of Atriplex nummularia. Australian Jour. Exp. Biol. and Med. Sei. 11 : 237-252.

\section{THE INFLUENCE OF SEVERAL BENZENE DERIVATIVES ON THE ROOTS OF LUPINUS ALBUS ${ }^{1}$ \\ Mother Mary Chrysostom}

Benzene substiturion products have long afforded a very attractive field of research to the chemist and bacteriologist and, more recently, to the plant pathologist. To the chemist, the ease of preparation of these substances and the evident correlation between their chemical properties and their structure present almost unlimited scope for investigation. The bacteriologist early discovered their antiseptic value and is now following the chemist in testing the newer derivatives for possible use as antiseptics and germieides. Literature in this field is voluminous and constantly being augmented. Owing to the fact that various plant products are benzene derivatives of tentimes formed in the course of destructive metabolism, the plant pathologist is beginning to consider their presence in the tissue as the active principle of im-

1 Received for publication April 3, 1936.

The writer wishes to express her deep gratitude to Professor Rodney H. True for suggesting the problem and for his unfailing interest during the course of the work, and to Doctor John R. Sken for his kind assistance in reading the manuscript. munity to certain diseases. Such investigations have stimulated research on the use of many of these substances as fungicides and germicides.

There is a decided paucity of literature, however, on the benzene compounds in relation to the higher plants. True and Hunkel (1898) investigated the influence of several phenols, aromatic acids, and their salts on Spirogyra and the roots of Lupinus albus. They concluded that the toxic effect of the benzene nucleus was modified to a greater or less degree by the introduction of various radicals into it. Brown and Tinker $(1916 \mathrm{a}, 1916 \mathrm{~b})$, in their studies on the permeability of the seed coats of Hordeum vulgare, found that various phenols were rapidly absorbed. Brenchley (1918), in a study of the effects of phenols on barley and peas with the possible use of these substances for soil sterilization, found that high concentrations were very toxic to the roots, while weak concentrations did not seem to retard growth. Recently, Eisenmenger (1931) studied the effect of silica gel in modifying the toxicity of phenol to soy bean 